\title{
Where Do "Impatient" Mutual Funds Invest? A Special Attraction for Large Proximate Markets and Companies with Strategic Investors
}

\author{
Claude Dupuy¹, Stéphanie Lavigne², Dalila Nicet-Chenaf ${ }^{3}$ \\ ${ }^{1}$ University of Bordeaux, GREThA, Bordeaux, France \\ ${ }^{2}$ Toulouse Business School, University of Toulouse, Toulouse, France \\ ${ }^{3}$ University of Bordeaux, LAREFI, Bordeaux, France \\ Email: claude.dupuy@u-bordeaux.fr, s.lavigne@tbs-education.fr,dalila.chenaf-nicet@u-bordeaux.fr
}

How to cite this paper: Dupuy, C., Lavigne, S. and Nicet-Chenaf, D. (2016) Where Do "Impatient" Mutual Funds Invest? A Special Attraction for Large Proximate Markets and Companies with Strategic Investors. Journal of Mathematical Finance, 6, 502-523. http://dx.doi.org/10.4236/jmf.2016.64040

Received: May 24, 2016

Accepted: September 27, 2016

Published: September 30, 2016

Copyright $\odot 2016$ by authors and Scientific Research Publishing Inc. This work is licensed under the Creative Commons Attribution International License (CC BY 4.0). http://creativecommons.org/licenses/by/4.0/

\begin{abstract}
Our study examines the investment determinants of worldwide mutual funds from the perspective of economic geography. In particular, we investigate the local preferences of "impatient" mutual funds for specific countries. By analyzing a sample of 22,996 worldwide mutual funds over the period from 2005 to 2009, we demonstrate that impatient mutual funds are favorable to 1) large stock markets, 2) markets with a high level of protection for shareholders, 3) markets with familiar institutional practices, and 4) markets dominated by the presence of "strategic" investors as main shareholders of large listed companies.
\end{abstract}

\section{Keywords}

Geography of Finance, Mutual Funds, Impatient Investors, Portfolio Turnover

\section{Introduction}

Since June 2007, global finance has faced a crisis of great magnitude. The subprime financial crisis, initially regarded as a crisis of the US housing market, soon spread to the international financial system confirming the globalization of equity markets. If the globalization of stock markets and ICT (information and communication technologies) enable investors to invest in all markets, globalization does not prevent them from developing local strategies. Indeed if capital flows theoretically can be invested everywhere (global strategies), the distribution of capital flows in global markets reveals their concentration in some markets (financial centers) [1] [2]. A large number of recent studies, under the banner of "geography of finance," have stressed that geographical location is 
a crucial determinant for understanding global finance ${ }^{1}$ : local specificities of capital markets remain one of the determinants of the localization of investor flows (local strategies). To consider these two aspects of investor strategies, some economists use the word of "glocalization," which is formed by blending "global" and "local" (The Oxford Dictionary of New Words, 1991).

Generally, to understand several aspects of investor localization strategies, standard portfolio models are used but they present some limits. Indeed, according to these models, assets are purchased on the basis of investor analysis regarding the return and risk of these assets and the covariance of these returns with other financial assets in the investment portfolio [10]. The capital asset pricing model (CAPM) is the most widely used tool in asset pricing theory and implies that investors select optimal portfolios that either minimize the variance of portfolio return, given expected return, or maximize the expected return, given variance. In the framework of CAPM model, rational investors who focus on risk-return factors should maximize international portfolio diversification without regard for the origin of the securities held. Prospect theory and behavioral portfolio models make different predictions. Contrary to standard financial models that postulate rationality on the part of investors, prospect theory considers that investors are not effective decision makers under risk and uncertainty [11]. Although the CAPM model enables investors to choose optimal portfolios, behavioral portfolio models state that investors are sensitive to the context in which they find themselves and may be characterized by heuristical traits such as overconfidence, extrapolation, or making frequency judgments based on salience or similarity [12]. Behavioral portfolio models are consistent with the existence of "familiarity effects" and with the "home bias" phenomenon. Despite the supposed benefits of diversifying into foreign markets, investors from all over the world tend to be biased toward investing in domestic equities. Even in a context of decline in barriers to international investment, investor portfolios are less diversified than the standard model of asset location would predict. Investors neglect fundamental principles of portfolio diversification by favoring proximate assets and markets: they feel safer with domestic than with foreign assets and, being averse to risk, they prefer familiar gambles over unfamiliar gambles. There is a large literature on the home bias phenomenon highlighting an [over-representation of domestic investments to the detriment of international portfolio diversification ([13][23]). Our study lies in the tradition of these works on home bias, but it is original because we seek to analyze the influence of geography on the investment strategies of investors according to their investment time horizons measured through their portfolio turnover.

In particular, we question the preference of mutual funds for some specific markets. Mutual funds are currently dominant in terms of assets managed on global stock markets because they reflect $75 \%$ of the financial assets of institutional investors. They are considered to be key actors in global stock markets because of their common expecta-

${ }^{1}$ See in particular [2]-[9]). 
tions regarding standards of disclosure, transparency, and their requirements for shareholder value ([6] [24]-[27]). A majority of the studies have emphasized that these investors expect increased returns on invested capital in a shorter time period ([5] [28]-[32]). In particular, the study of Dupuy, Lavigne, and Nicet-Chenaf (2010) [32]), describing the largest international equity investors, showed that US institutional investors are the most volatile and "impatient" actors worldwide, confirming the very short-term nature of the US model.

Our study focuses on the geographical location of assets managed by worldwide mutual funds and particularly on impatient mutual funds, that is, investors whose portfolio turnover is less than one year. These short-term investors, who are regularly identified by the economic and financial press and accused of favoring volatility in equity markets, often sell their stocks before companies have paid dividends and play on differences in stock prices to extract a short-term profit. In particular, we question the determinants of location of impatient mutual funds by focusing on two main questions: 1) where do impatient mutual funds invest internationally and 2) what are the local specificities of markets that are privileged when these investors internationalize their portfolios?

The article is organized into four sections. Section 2 introduces theoretical aspects of the importance of geography in global finance and reviews the importance of the institutional framework for understanding the investment behavior of mutual funds. Section 3 presents a sample of 22,996 worldwide mutual funds and the practical results of their global behavior on stock markets in 2009 and over the period from 2005 to 2009 . Section 4 presents the methodology used to test the preference of impatient mutual funds for certain stock markets. In particular, we demonstrate that impatient mutual funds prefer investing in large stock markets characterized by the same legal tradition and presence of strategic investors in ownership structures.

\section{When Geography and Institutions Help Explain Investor Behavior}

We question if local specificity of capital markets can play a significant role in explaining the worldwide allocation of mutual fund portfolios. In particular, we make the assumption that the 6 geography (countries) and the institutional framework (legal regimes of countries and shareholder protection) are central elements for understanding the investment behavior of mutual funds. We thus refer to two fields of research to demonstrate the centrality of those two factors: the literature on the geography of finance and law and finance literature.

\subsection{Geography of Global Finance}

Our study contributes to a growing and recent literature on the economic importance of geography in understanding global finance ([5] [33] [34]). The main argument in support of the geography of global finance concerns the exceptional development of stock markets, the importance of capital flows, and the weight of institutional investors 
in those flows ([4] [5] [28] [34] [35]). A large number of studies have highlighted the growth of a financial services industry developed around institutional investors ([5] [24] [25] [32] [36] [37]).

As argued by Clark and Wójcik (2007) [5], global finance comes from certain origins and it flows to certain destinations. In this article, we refer to studies that question the behavior of mutual funds and in particular the destinations of their flows. Many studies on the home bias have shown that proximity plays an important role in determining investor portfolio choices: investors prefer geographically proximate investment for their portfolios ([15] [17]-[19] [23] [38]). In particular, the study [15] on equity holdings by mutual funds for 1991 and 1992 reveals that mutual funds prefer investing in stocks with high visibility and low transaction costs and are averse to small firms, low-priced stocks, and stocks with low idiosyncratic volatility. Although this study gives evidence of the ability of mutual funds to select stocks, it says little concerning the geographical dimension.

We refer to recent studies that highlight the importance of geography for understanding the investment behavior of worldwide mutual funds. In their 2001 study, Coval and Moskowitz [38] documents a geographical link between the investments and performance of mutual funds. Their study shows that mutual fund managers earn abnormal returns in their geographically proximate investments. The authors explain the substantial abnormal return by the information mutual funds may have acquired about local companies: mutual fund managers have access to private information of geographically proximate firms. The study of Coval and Moskowitz [38] concludes that the extent to which a company is held by nearby investors is positively associated with its future expected returns, attesting to an informational link between geography and investment decisions. Clark and Wójcik (2002) [39] asked how and where portfolio managers should invest in Europe while considering a basic question: should investment strategies be based on industries or countries? They demonstrate that geography helps explain the decisions of mutual fund managers: country-based strategies remain fundamental because markets differ in terms of corporate governance. In particular, they notice important differences between Anglo-Saxon markets and continental European markets that influence the investment strategies of mutual funds. Their study also questions the relationship between European stockholder ownership and the volatility of corporate stock market prices. They document a negative relationship between European stock price volatility and ownership concentration, proving once again the importance of geography. In the same vein, the study of Clark, Wójcik, and Bauer (2006) [40] showed a negative relationship between the quality of corporate governance and stock price volatility. Clark and Wójcik (2007) [5] carried out a study on portfolio managers, the issue being whether they are better placed to pursue a passive-index strategy or an active-investment strategy in the specific case of the German industry. They demonstrated that closed ownership structures promote higher volatility in quoted market prices and that the incursion of global portfolio managers into European stock markets has had significant effects on corporate governance. Indeed, some of Eu- 
rope's largest companies have responded to investor activism with substantial changes in corporate governance in order to become more consistent with the expectations of global financial markets.

If all these studies have highlighted the importance of geography in understanding mutual fund behavior on stock markets, very few have asked this question in relationship to the portfolio turnover of mutual funds. The oldest study is by Tesar (1995) [14] who found that the turnover for international investments of US and Canadian funds is ten times higher than in domestic shares. However, using data on gross transactions in foreign stocks available in the United States and Canada, Warnock (2002) [41] relativized this work by showing that the turnover is slightly higher than abroad.

Two recent studies have addressed these issues with two different approaches to the turnover. Dupuy, Lavigne, and Nicet-Chenaf (2010) [32] studied the portfolio turnover of 11,900 mutual funds. They tested the relationship among the type of equity investor, its portfolio turnover, and its geographical origin, measured through its attachment to a specific model of capitalism ([42]). They demonstrated that US investors are the most volatile and impatient investors in the world and they compared the proximity of investors from different countries with US investors. Their study shows that the US market-based model is clearly the most active in terms of portfolio turnover management, confirming that this country is the archetype of a "finance-driven" system. Dupuy, Lavigne, and Nicet-Chenaf (2010) [32] demonstrated that differences in frequency of securities trading are largely explained by the geographical origin of investors, attesting that geography is central for understanding the behavior of key actors on global stock markets. The most recent study is by Chan and Covrig (2012) [43] who analyze the behavior of mutual funds in 29 countries over a 10 -year period. The main contribution of this study is to show how the asymmetry of information and familiarity affect the portfolio rebalancing of foreign equities. Mutual funds turn over foreign stocks more frequently than domestic ones. Regarding the familiarity effect, they posit that the closer two countries are to each another, meaning that fund managers are more familiar with the target country, the less frequently the fund managers will rebalance those foreign holdings. They observe that the churn rates are higher for the stocks of companies located in countries that have more asymmetric information and are less familiar to fund managers.

In the vein of these previous works, we question the preference of mutual funds for certain stock markets (in particular, markets with the same legal origins as the investor's own country).

\subsection{Law and Finance Literature}

The recognition that geography matters leads implicitly to the assertion that the institutional framework (laws and their enforcement) is central to understand the behavior of investors ${ }^{2}$. A large number of academic works have emphasized the importance of legal

${ }^{2}$ Quality of law enforcement designs the quality of ensuring observance and obedience to laws. 
systems for understanding differences among countries in terms of stock market development, financing of companies, and standards of corporate governance ([44]-[46]). It is recognized that laws and the quality of their enforcement are determinants of 1) the level of development of financial markets, 2) the number of listed companies on stock markets, 3) the ownership concentration in publicly traded firms, 4) the rate of initial public offerings (IPOs), or 5) dividend policies, to name just a few examples. The commercial legal systems of most countries derive from specific legal traditions, including, on the one hand, the English common law, and, on the other hand, the French and German traditions deriving from Roman law, with Scandinavian countries forming their own tradition. La Porta et al. (2000) [46] demonstrated on a sample of 49 countries that common law countries afford the best legal protection to outside investors regarding a large number of criteria (one share-one vote, proxy 10 by mail, cumulative voting, etc.), whereas civil law countries offer the worst legal protection to shareholders. In particular, civil law countries exhibit the lowest aggregate anti-director rights score, an index that measures how strongly a legal system favors minority shareholders against managers or controlling shareholders in the corporate decision process ${ }^{3}$. Common law countries afford the best legal protection to shareholders because they allow investors to vote by mail, never block shares before shareholder meetings, and require only a small share of capital to call an extraordinary shareholder meeting. Although common law countries protect investors better than countries with civil law traditions, German civil law and Scandinavian countries have the best quality of law enforcement, the French civil law system has the worst ${ }^{4}$. Similar to Shleifer and Vishny (1997), La Porta et al. (2000) and Dahlquist, Pinkowitz, Stulz, and Williamson (2003) [46]-[48] demonstrated that companies in countries with poor protection of shareholders have more concentrated ownership of their shares: in a context of poor investor protection, ownership concentration is extremely high and becomes a substitute for legal protection. By far the highest concentration of ownership is to be found in civil law countries (the average ownership by the three largest shareholders is $54 \%$ compared to $20 \%$ for the US system $)^{5}$. In countries with poor shareholder protection, the largest firms have controlling shareholders, attesting that concentration of ownership is an adaptation to poor legal protection. Dahlquist et al. (2003) [48] have shown that there is indeed a re-

${ }^{3}$ The anti-director rights index, ranging from 0 to 6 , is formed by adding one when 1 ) the country allows shareholders to mail their proxy to vote, 2) shareholders are not required to deposit their shares prior to the general shareholder meeting, 3) cumulative voting is allowed, 4) oppressed minorities mechanisms are in place, 5) the minimum percentage of share capital to call an extraordinary shareholder meeting is less than or equal to $10 \%$, and 6) shareholders have preemptive rights that can be waived only by shareholder vote (see [46]).

${ }^{4}$ Concerning law enforcement, [46] use indicators to determine whether a system gives enough investor protection. They refer to five indicators and to an estimate of the quality of a country's accounting standards: efficiency of the judicial system, rule of law, corruption, risk of expropriation, and the likelihood of contract repudiation by government. Laws can be enforced by market regulators, courts, or market participants. ${ }^{5}$ In the world as a whole, the average ownership of the three largest shareholders is $46 \%$ and the median is $45 \%$. In short, the idea of dispersed ownership in large public companies is a myth. Even in the United States, the average for the 10 most valuable companies is $20 \%$ (see [46] p. 1146). 
lationship between the degree of presence of insiders (that we refer to as "strategic" investors) and the presence of mutual funds, which depends on the level of liquidity. When a firm's ownership is concentrated, the availability of shares is limited and the frequency of trade is reduced. Mutual funds, which are usually minority shareholders, can exchange stocks only that are not held by strategic investors (who can be a family, the state, etc.) and invest less in countries where large shareholders own a high fraction of equity.

\section{The Mutual Funds Industry: A Geographically Concentrated Industry}

Our study covers a sample of 22,996 international mutual funds investing in 35 countries $^{6}$. Mutual funds are the largest category of institutional investors in financial markets, the major actors on international stock markets [25] and their assets have grown explosively in most countries around the world during the 1990s and the 2000s. The data on mutual funds are drawn from the Thomson One Banker Ownership (TOBO) database, the leading information source for registering international capital flows and investor equity portfolios across international stock markets. The database provides data for analysts, investment bankers, portfolio managers, and researchers and covers the portfolios of approximately 40,000 institutional investors from 1997. We have selected the largest worldwide mutual funds, i.e. those managing portfolio assets in equities over $\$ 20$ billion. In accordance with many prior studies on mutual funds, we have restricted our analysis to equity mutual funds. Our sample is composed of equity funds that invest 1) a part of their assets in foreign markets (they are not domestic mutual funds); 2) in all types of company in terms of capitalization; 3 ) in all types of industry.

The data indicate that the mutual funds industry is geographically concentrated in two geographic areas (North America and Europe), which accounted for $89.19 \%$ of global funds in 2009. Over the period of analysis (2005-2009), which includes the US subprime crisis, there was a decline in the European share of mutual fund managers: whereas $29 \%$ of mutual funds came from Europe in 2005, the figure was only $23 \%$ in 2009, showing the decline of Europe as the origin of mutual funds. However, there was strong growth in the proportion of funds in two other geographical areas, Asia and Latin America: 2\% of mutual funds were of Asian origin in 2005 against 4\% in 2009, and 5\% of investors were of Latin American origin in 2005 against 24\% in 2009. As for the weight of the North American area, it remains very stable over the period and accounts for about $62 \%$ of all mutual funds (Table 1 ).

At the country level, five countries (United States, United Kingdom, Canada, Germany, and France) account for $82 \%$ of the assets of the global mutual funds industry, again attesting to the high concentration of the sector.

If we now examine where mutual funds invest, in relation to their country of origin, it is difficult to observe a geographical diversification of their portfolios. Portfolio

\footnotetext{
${ }^{6}$ Appendix 1 presents the list of countries and their market capitalization.
} 
Table 1. Origin of mutual funds by countries.

\begin{tabular}{|c|c|c|c|c|}
\hline & Ranking in 2005 & 2005 & Ranking in 2009 & 2009 \\
\hline 1 & United States & $61.6 \%$ & United States & $61.60 \%$ \\
\hline 2 & United Kingdom & $12.5 \%$ & United Kingdom & $10.07 \%$ \\
\hline 3 & Germany & $4.8 \%$ & Canada & $3.95 \%$ \\
\hline 4 & Canada & $3.9 \%$ & Germany & $3.38 \%$ \\
\hline 5 & Sweden & $2.6 \%$ & France & $2.98 \%$ \\
\hline 6 & France & $2.4 \%$ & China & $2.55 \%$ \\
\hline 7 & Japan & $1.8 \%$ & Japan & $1.99 \%$ \\
\hline 8 & Switzerland & $1.4 \%$ & Sweden & $1.52 \%$ \\
\hline 9 & Ireland & $1.0 \%$ & Switzerland & $1.50 \%$ \\
\hline 10 & Belgium & $0.7 \%$ & Brazil & $1.41 \%$ \\
\hline 11 & Bahamas & $0.7 \%$ & Hong Kong & $1.03 \%$ \\
\hline 12 & Italy & $0.7 \%$ & Mexico & $0.92 \%$ \\
\hline 13 & Singapore & $0.7 \%$ & Singapore & $0.85 \%$ \\
\hline 14 & Netherlands & $0.6 \%$ & Netherlands & $0.49 \%$ \\
\hline 15 & Hong Kong & $0.5 \%$ & India & $0.48 \%$ \\
\hline 16 & India & $0.5 \%$ & Belgium & $0.47 \%$ \\
\hline 17 & Spain & $0.4 \%$ & Bahamas & $0.46 \%$ \\
\hline 18 & Denmark & $0.4 \%$ & Ireland & $0.46 \%$ \\
\hline 19 & Norway & $0.3 \%$ & Australia & $0.41 \%$ \\
\hline \multirow[t]{2}{*}{20} & Luxembourg & $0.3 \%$ & Denmark & $0.39 \%$ \\
\hline & Total & $100 \%$ & Total & $100 \%$ \\
\hline
\end{tabular}

Source: Thomson one banker ownership, Thomson financial, 2009.

concentration, mimetic behavior, and home $\operatorname{bias}^{7}$ (i.e., high share of the total portfolio invested in domestic assets) are more appropriate strategies for mutual funds. Mutual funds invest as a priority in their own geographic area and especially when they originate from areas with well-developed financial markets (Table 2).

For instance, North American funds invest $92 \%$ of their assets in North America and European funds invest $57 \%$ of their assets in Europe. For South American funds, the relative weakness of the capital invested in their domestic area can be explained by the proximity of the North American market.

When we turn to the analysis of where impatient mutual funds invest, we find the same configuration as in Table 1: home bias and concentration of portfolios on certain geographical areas are the two main features. However, the aim of the study is not to

${ }^{7}$ The theory of diversification of portfolios explains that investing in foreign equities can help lower the amount of systematic risk in a portfolio because foreign investments are less likely to be affected by domestic market changes. However, despite the purported benefits of diversifying into foreign markets, investors from all over the world tend to be biased toward investing in domestic equities (home bias). This bias is notably explained by the difficulty of investing abroad and in particular by the additional transaction costs or legal restrictions. 
Table 2. Where do Mutual Funds (MF) invest: a regional preference?

\begin{tabular}{cccccc}
\hline $\begin{array}{c}\text { Geographic } \\
\text { areas }\end{array}$ & African MF & $\begin{array}{c}\text { Asian } \\
\text { MF }\end{array}$ & $\begin{array}{c}\text { European } \\
\text { MF }\end{array}$ & $\begin{array}{c}\text { South American } \\
\text { MF }\end{array}$ & $\begin{array}{c}\text { North American } \\
\text { MF }\end{array}$ \\
\hline Africa & $25 \%$ & $0 \%$ & $0 \%$ & $0 \%$ & $0 \%$ \\
Asia & $2 \%$ & $46 \%$ & $2 \%$ & $4 \%$ & $0 \%$ \\
Europe & $31 \%$ & $18 \%$ & $57 \%$ & $28 \%$ & $7 \%$ \\
Latin America & $1 \%$ & $1 \%$ & $5 \%$ & $24 \%$ & $1 \%$ \\
North America & $41 \%$ & $34 \%$ & $36 \%$ & $44 \%$ & $92 \%$ \\
Total & $100 \%$ & $100 \%$ & $100 \%$ & $100 \%$ & 100 \\
\hline
\end{tabular}

Source: Thomson one banker ownership, Thomson financial, 2009.

address the question of home bias (i.e., the tendency of investors to invest heavily in domestic equity). Instead, we investigate what kind of country is selected by mutual funds, and especially by impatient mutual funds, when they decide to invest abroad.

We now test the following two propositions: that 1) geographical and institutional origin of countries influence mutual fund choices of location and 2) some countries have characteristics that make them more attractive to impatient mutual funds (in particular the presence of strategic investors in the ownership structures of companies).

These propositions are first tested with two control variables: the market capitalization of countries and the size of mutual fund assets portfolios.

\section{When Impatient Mutual Funds Find Some Specific Characteristics of Host Countries Favorable: An Empirical Study}

In our empirical study we question whether some countries attract more impatient investors and why. We then investigate what kind of criteria (geographical and institutional) can explain the presence of impatient mutual funds in some specific markets. In the econometric analysis we consider the US market as a localization reference and we question the investment behaviors of worldwide mutual funds.

The empirical analysis involves two steps. First, we question the degree of relationship among investor portfolio turnover, their choices of location in 35 countries $^{8}$, and their portfolio size considered as a control variable (portfolio size is labelled EQUITY ASSET). The aim is to question if some markets are preferred by impatient mutual funds and to determine what the characteristics of these markets are. We tested whether the choice of location of investment may be influenced by geographical and institutional variables.

In a baseline model, we analyze the relationship between the portfolio turnover of investors and two variables: 1) the variable EQUITY ASSET and 2) the variable MARKETSIZE, which is the host country's market capitalization. For the latter variable we postulate a positive relationship between market size and a strong presence of impatient investors. In the vein of the CAP model, the idea is that large markets are more 
liquid and enable reducing some risks (uncertainty and illiquidity). We control investor preference for these two variables and we step-by-step introduce three independent variables: a) the presence of strategic entities in ownership structures of companies ${ }^{9}$ : with this variable labelled STRATEGIC we postulate a positive relationship between the presence of impatient investors and that of strategic investors as underlined by [48]; b) the degree of legal protection for shareholders (measured by the anti-director rights index; see [45]): with this variable labelled SHAREHOLDER we postulate mutual fund managers should prefer investing in stock markets that best protect their interests by offering a favorable legal environment ([46]; and c) the difference between the legal regime in the mutual fund's country of origin and the legal regime of the host country: with this variable labelled LEGAL ORIGIN we postulate that investors prefer investing in host countries that share the same origin of law because financial practices are closer and help reduce transaction costs and uncertainty.). Because of familiarity effects, if investors are from a country whose legal system is common law, they should prefer investing in countries with the same legal regime and same level of shareholder protection.

\subsection{Geographical Model and Methodology}

We extract two variables from the Thomson financial database: the amount of financial assets managed by mutual funds (EQUITY ASSET) and their portfolio turnover level (high, moderate, and low ${ }^{10}$. To include these qualitative variables in our empirical study, we consolidate the three levels of turnover (high, moderate, and low) into a single type of variable to enable a binary encoding ${ }^{11}$ : HIGH against NOT HIGH. If a mutual fund's turnover is high the variable takes a value of one and in all other cases (low and moderate turnover) the variable takes a value of zero.

The variable HIGH refers to impatient mutual funds, that is, mutual funds with a high portfolio turnover. Inversely, investors with a low or moderate turnover are called patient investors.

Regarding the methodology and the data analysis, we use a binary probit model to test the probability that a country $i$ rather a country $j$ receive an investment from an impatient mutual fund. The sample consists of $\mathrm{j}$ mutual funds indexed by $\mathrm{j}=1, \cdots$, 22,996 and where index $i$ represents the country $(i=1, \cdots, 35)$ in which mutual funds invest. Estimations are made for the year $2009^{12}$.

We thus consider $\mathrm{Yi}$, a dependent $\mathcal{\varepsilon}[1, \mathrm{~N}])$ :

$\mathrm{Yi}=1$ if the condition "have a high turnover" is true for mutual funds $\mathrm{j}$ investing in

${ }^{9}$ The Thomson financial database registers investors and opposes institutional investors (mutual funds, pension funds, etc.) to strategic investors (family, state). We replicate this typology of investors in our study. Strategic investors are generally insiders: large shareholders or controlling shareholders in companies.

${ }^{10} \mathrm{We}$ consider an impatient investor to be any shareholder whose portfolio turnover is qualified as high in the Thomson financial database. High portfolio turnover refers to a holding period of portfolios of less than 12 months. Moderate portfolio turnover refers to a holding period between 12 months and 24 months. Low portfolio turnover refers to a holding period of more than 24 months.

${ }^{11}$ For the variable high: if the investor's turnover is high the variable takes the value of one and in all other cases (low and moderate portfolio turnover) the variable takes the value of zero.

${ }^{12} \mathrm{We}$ checked that results are the same for the year 2005 . 
country i

$\mathrm{Yi}=0$ if the condition "have a turnover different from high" is true for mutual funds $j$ investing in country $i$

With the probit model regression, we assess the probability of occurrence of the event "have a high turnover" considering two dependent variables (xi: the host country $\mathrm{i}$ and $\mathrm{x} 2$ : equity asset).

We also propose a second binary probit model to test the probability that a country $i$ rather a country $\mathrm{j}$ receive an investment from a patient investor. We thus consider $\mathrm{Yi}$, dependent variable, coded $(0,1)$ and associated with these events $\varepsilon[1, \mathrm{~N}])$ :

$\mathrm{Yi}=1$ if the event "have a low turnover" occurs for mutual funds $\mathrm{j}$ investing in country $\mathrm{i}$

$Y i=0$ if the event "have a turnover different from low" occurs for mutual funds $j$ investing in country $\mathrm{i}$

We assess the probability of occurrence of the event "have a low turnover" considering the same two dependent variables ( $x$ i: the host country $i$ and $x 2$ : equity asset). The models are estimated by the maximum likelihood method using the US market as a reference. The results with the dependent variable high are presented in Table 3 and those with the dependent variable low are presented in Appendix 2.

In Table 3 the coefficient column indicates marginal effects that measure the model's sensitivity to changes in turnover relative to the US market. Column Prob (z) measures the probability associated with the significance tests. In the first estimation numerous coefficients are significant beyond the .01 level of confidence $(\mathrm{P}[\mathrm{Z} />\mathrm{z}]<0.000)$.

$\mathrm{dy} / \mathrm{dx}$ is for discrete change of dummy from 0 to 1 The estimation shows that there are two types of investor strategies in relation to the US market: investment is less likely to come from an impatient mutual fund than from a patient mutual fund for the following countries: Australia, Canada, China, Denmark, Greece, Ireland, Japan, Korea, Mexico, Norway, Portugal, South Africa, and Taiwan. Conversely, investment is more likely to come from an impatient mutual fund than from a patient mutual fund for the following countries: Argentina, Austria, Belgium, Brazil, Finland, India, Italy, the Netherlands, Sweden, Thailand, and the United Kingdom.

Globally, we can underline that countries with significant negative elasticities (Australia, Canada, China, Taiwan, Japan, Korea, Mexico and Taiwan,) are countries where impatient mutual funds do not prefer investing and countries with significant positive elasticities (Austria, Belgium, Italy, Finland, and the Netherlands) are countries where they prefer investing. It is not possible to conclude for the specific case of France, Germany, or Switzerland because their elasticities are not significant.

At this stage, if certain countries seem to be privileged destinations for impatient mutual funds, the model does not say why. The study now proposes to deepen our understanding of this preference for certain markets.

\subsection{Model with Institutional Criteria: Presence of Strategic Investors as a Determinant of Location}

Although we can highlight preferences of impatient mutual funds for some specific host 
Table 3. "Impatient" mutual funds' location strategies (controlled by the equity asset, variable: "High") (Probability of the characteristic $\mathrm{Y}=1$, with the US as a reference).

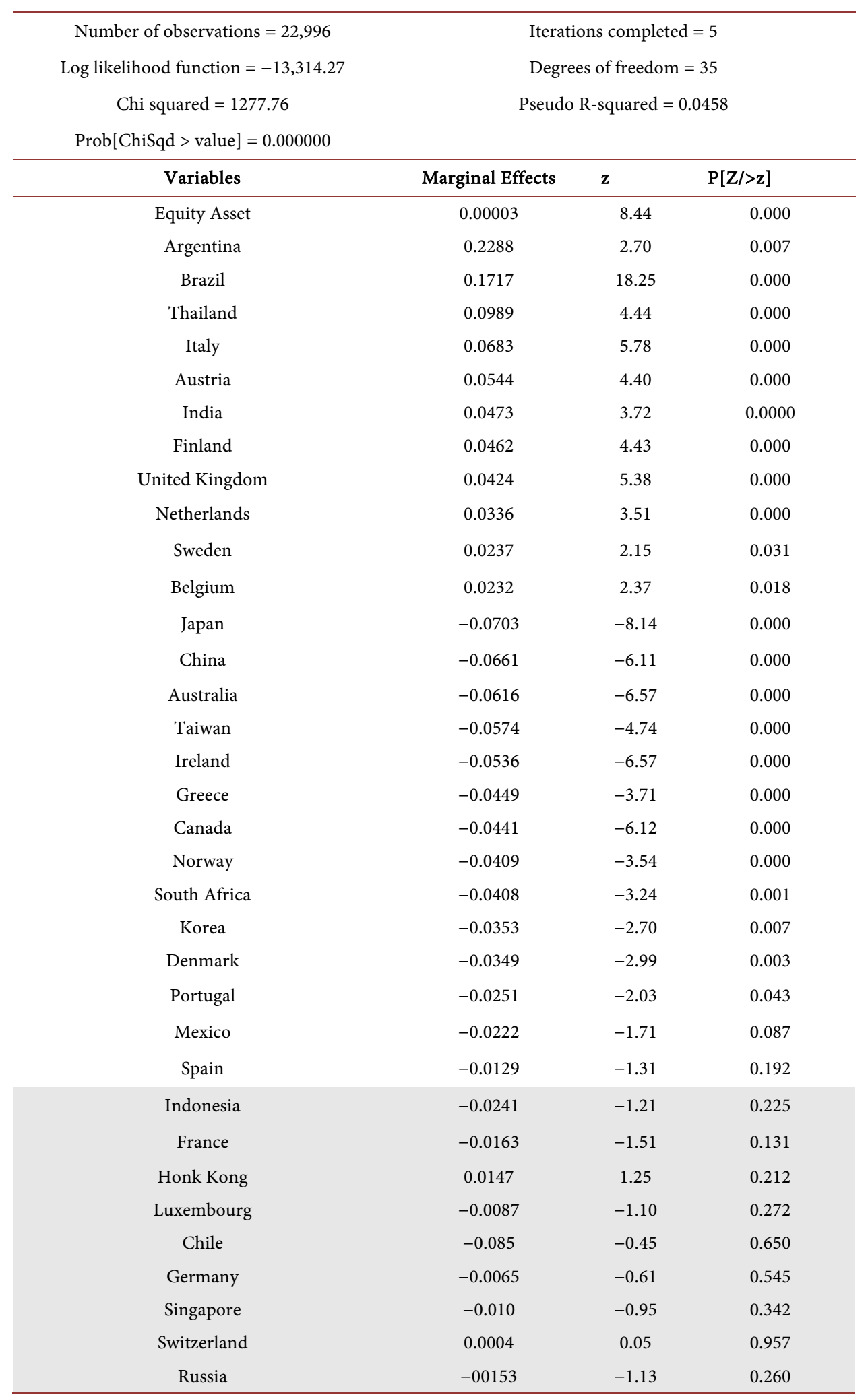

In the grayed parts, variables are not significant. 
countries, the previous model tells us little about the determinants of this location. We now make the assumption that these location strategies may be determined by four variables that we have constructed in our database: 1 ) the size of the markets (measured by market capitalization) that we label MARKETSIZE; 2) the percentage of capitalization held by strategic entities labelled STRATEGIC; 3) the difference between the origin of the legal system in the investor domestic market and host countries, labelled LEGAL ORIGIN OF LAW; and 4) shareholder protection measured by the level of anti-director rights, labelled SHAREHOLDER.

By introducing capital market size in our analysis we assume that market capitalization offers the liquidity necessary for the strategies of impatient mutual funds. The size of markets is next considered as a control variable in our baseline model.

To consider the influence of the host country's size on the choice of location of mutual funds, we construct four qualitative variables: MARKETSIZE intermediate, MARKETSIZE large, MARKETSIZE small, and MARKETSIZE all. MARKETSIZE large is used when mutual funds invest only in large markets ${ }^{13}$, MARKETSIZE small is used when they invest only in small markets and MARKETSIZE intermediate when mutual funds invest only in intermediate markets. MARKETSIZE all is our benchmark and refers to cases in which mutual funds can invest in all kinds of markets (see Table 4(a) and Table $4(\mathrm{~b}))$.

Dahlquist et al. (2003 [48] have shown that there is a relationship between the degree of presence of insiders (or strategic entities) in the ownership structures of companies and the presence of mutual funds. We now analyze the ownership structures of the 35 countries composing our sample while considering, on the one hand, the percentage of stocks owned by institutional investors and, on the other hand, the percentage of stocks owned by strategic entities (the state, families, etc.). This enables us to consider two groups of countries: those coming from the common law tradition, exhibiting a higher level of institutional investors in their ownership structures, and those originating from the civil law tradition, characterized by the presence of large shareholders in their ownership structures (see Table 5).

To introduce differentiated strategies of mutual funds according to the presence (or not) of strategic entities in the capital of large listed companies, we created three qualitative variables: STRATEGIC all, STRATEGIC strong, and STRATEGIC few. STRATEGIC strong is used when mutual funds invest only in markets with a strong presence of strategic investors ${ }^{14}$; STRATEGIC few designates cases in which mutual funds invest only in markets with few strategic investors; STRATEGIC all is our benchmark and occurs when mutual funds invest in both kinds of market ${ }^{15}$.

We also include the variable SHAREHOLDER, which is the anti-director index (ranging from 0 to 6). It measures how strongly the legal system favors minority share-

\footnotetext{
${ }^{13}$ If mutual funds invest only in a market, the variable takes the value one and, if not, the variable takes the value zero.

${ }^{14}$ If mutual funds invest only in markets where there is a strong presence of strategic investors, the variable takes the value one and zero in all other cases.

${ }^{15}$ Strong presence corresponds to cases when there is more than $35 \%$ strategic investor; weak presence correspond to cases when there is less than $35 \%$ strategic investors.
} 
Table 4. (a) Baseline model-Investors' location strategies-Dependent Variable "High". (b) Baseline model-Investors' location strategies-Dependent Variable "High".

(a)

\begin{tabular}{|c|c|c|}
\hline \multicolumn{3}{|c|}{$\begin{array}{c}\text { Number of observations }=22,996 \\
\text { Time period } 2009 \\
\text { Pseudo R2 }=0.049 \\
\text { LR Chi Squared }=146.04^{\star * *} \\
\text { Log Likelihood function }-14,809.793\end{array}$} \\
\hline Independent Variables & Standardized coeff. & Marginal effects (dy/dx) \\
\hline Equity Asset & $0.103^{\star * *}(7.12)$ & $0.0000157^{\star * *}(7.14)$ \\
\hline Marketsize $_{\text {small }}$ & $-0.072^{\star \star \star}(-6.37)$ & $-0.088^{\star \star \star}(-6.13)$ \\
\hline Marketsize $_{\text {intermediate }}$ & $-0.057^{\star \star \star}(-4.51)$ & $-0.064^{\star \star \star}(-4.76)$ \\
\hline Marketsize large $_{\text {la }}$ & $0.053^{\star * *}(6.11)$ & $0.045^{\star * \star}(6.25)$ \\
\hline
\end{tabular}

$\mathrm{p}$-value: ${ }^{*} \mathrm{p}<0.10 ;{ }^{* *} \mathrm{p}<0.5 ;{ }^{* *} \mathrm{p}<0.01$. Note: values in parentheses are $\mathrm{z}$-statistic. Note: $\mathrm{dy} / \mathrm{dx}$ is to discrete change of dummy variable from 0 to 1 .

(b)

\begin{tabular}{ccc}
\hline & Number of observations $=24,529$ & \\
& Time Period 2005 & \\
& Pseudo $2=0.066$ & \\
& LR Chi Squared $=197.10^{* * *}$ & \\
& Log Likelihood function $-14,784.264$ & \\
\hline Variables & Standardized coeff. & Marginal effects $(\mathrm{dy} / \mathrm{dx})$ \\
Equity Asset & $1.00^{* * *}(7.87)$ & $0.0000378^{* * *}(7.94)$ \\
Marketsize $_{\text {small }}$ & $-1.478^{* *}(-6.23)$ & $-0.085^{* * *}(-5.93)$ \\
Marketsize $_{\text {intermediate }}$ & $-0.722^{* * *}(-6.14)$ & $-0.063^{* * *}(-4.80)$ \\
Marketsize $_{\text {large }}$ & $0.796^{* * *}(4.48)$ & $0.045^{* * *}(6.32)$ \\
\hline
\end{tabular}

$\mathrm{p}$-value: ${ }^{*} \mathrm{p}<0.10 ;{ }^{* *} \mathrm{p}<0.5 ;{ }^{* *} \mathrm{p}<0.01$. Note: values in parentheses are $\mathrm{z}$-statistic. Note: $\mathrm{dy} / \mathrm{dx}$ is to discrete change of dummy variable from 0 to 1 .

Table 5. Ownership structures of large companies in different geographical areas.

\begin{tabular}{cccccc}
\hline & North America & Australia & South Africa & Europe & Asia \\
\hline $\begin{array}{c}\text { Institutional } \\
\text { investors }\end{array}$ & $\mathbf{6 0 . 2 0 \%}$ & $\mathbf{5 6 . 8 4 \%}$ & $\mathbf{5 2 . 5 3 \%}$ & $44.33 \%$ & $39.39 \%$ \\
$\begin{array}{c}\text { Strategic entities } \\
\text { Stric }\end{array}$ & $39.98 \%$ & $43.16 \%$ & $47.47 \%$ & $\mathbf{5 5 . 6 7 \%}$ & $\mathbf{6 0 . 6 3 \%}$ \\
\hline
\end{tabular}

Source: Thomson one Banker Ownership, Thomson Financial, 2009.

holders against managers or dominant shareholders in the corporate decision-making process. We consider two cases: when 1) mutual funds invest in a country where the index value is between 0 and 2.5 and 2) mutual funds invest in a country where the index value is higher than 2.5. If the share of investments is realized in countries where the index value is low (i.e., weak protection), the variable SHAREHOLDER takes the value zero and one in the other cases. The variable SHAREHOLDER enables us to measure the tendency of mutual funds to prefer countries where the level of shareholder protection is high. 
Finally, the variable LEGAL ORIGIN measures the institutional distance between the host country and the domestic countries of investors. We consider two cases: when 1) mutual funds invest in markets where the legal regime is the same as the regime of law of its domestic country and 2) mutual funds invest in markets where the legal regime is different from its country of origin. If the share of investments in countries where the legal origin is the same as the mutual fund country and is superior to $50 \%$, the variable takes the value one and zero in the other cases. With the variable LEGAL ORIGIN, we measure the tendency of mutual funds to prefer investments in countries where the legal regime is the same as the legal origin of their own countries.

With these new variables, we again consider Yi, dependent variable, coded $(1,0)$ and associated with these events $\varepsilon[1, \mathrm{~N}])$ :

$\mathrm{Y} i=1$ if the event "have a high turnover" occurs for mutual funds $j$ investing in market i

$Y i=0$ if the event "have a turnover different from high" occurs for mutual funds $j$ investing in market $\mathrm{i}$

With this probit model we assess the probability of occurrence of the event "have a high turnover" considering five dependent variables (equity assets of mutual funds, market capitalization of host countries, presence of strategic investors, differences regarding legal origin, and level of anti-director rights). We use this second binary probit model to test the probability that an impatient mutual fund $\mathrm{j}$ rather than a patient mutual fund will invest in markets categorized by the five variables (see Table 6).

In the baseline model, each variable (excluding STRATEGIC few) has a significant coefficient. This probit model shows that being an impatient mutual fund rather than a patient mutual fund increases the probability of preferring to invest in markets with a

Table 6. Complete model Investors' location strategies-dependent variable "High".

\begin{tabular}{|c|c|c|c|}
\hline \multicolumn{4}{|c|}{$\begin{array}{c}\text { Number of observations }=22,996 \\
\text { Time period: } 2009\end{array}$} \\
\hline Variables & Standardized coeff. (2) & Standardized coeff. (3) & Standardized coeff. (4) \\
\hline Equity Asset & $0.102^{\star * \star}(7.06)$ & $0.102^{\star * *}(7.05)$ & $0.099^{\star * *}(6.860)$ \\
\hline Marketsize $_{\text {small }}$ & $-0.068^{* * *}(-5.87)$ & $-0.066^{* * *}(-5.67)$ & $-0.074^{* * *}(-6.28)$ \\
\hline Marketsize $_{\text {intermediate }}$ & $-0.05^{\star * *}(-4.24)$ & $-0.050^{\star * *}(-4.23)$ & $-0.049^{\star * \star}(-4.14)$ \\
\hline Marketsizelarge & $0.062^{\star * *}(5.10)$ & $0.062^{* * *}(5.08)$ & $0.057^{\star * *}(4.67)$ \\
\hline Strategic Investors $_{\text {strong }}$ & $0.025^{\star * *}(2.08)$ & $0.029^{* * *}(3.21)$ & $0.028^{* * *}(3.09)$ \\
\hline Strategic Investors $\mathrm{few}_{\mathrm{f}}$ & $0.004(0.36)$ & $0.004(0.35)$ & $0.002(0.20)$ \\
\hline Shareholder protection & - & $-0.031^{\star * \star}(-3.67)$ & $-0.038^{\star * *}(-4.35)$ \\
\hline Institutional distance & - & - & $0.031^{\star * *}(3.64)$ \\
\hline \multirow{4}{*}{ Statistics } & Pseudo $\mathrm{R}^{2}=0.052$ & Pseudo $\mathrm{R}^{2}=0.056$ & Pseudo $\mathrm{R}^{2}=0.057$ \\
\hline & $\operatorname{LR} \chi^{2}=154.36^{* * *}$ & $\operatorname{LR} \chi^{2}=167.85$ & $\operatorname{LR} \chi^{2}=186.95$ \\
\hline & Log Lik. Funct & Log Lik funct & Log Lik. funct \\
\hline & -14805.633 & -14798.838 & -14789.342 \\
\hline
\end{tabular}

$\mathrm{p}$-value: ${ }^{*} \mathrm{p}<0.10 ;{ }^{* *} \mathrm{p}<0.5 ;{ }^{* *} \mathrm{p}<0.01$. Note: values in parentheses are $\mathrm{z}$-statistic. Note: $\mathrm{dy} / \mathrm{dx}$ is to discrete change of dummy variable from 0 to 1 . 
strong presence of strategic investors (STRATEGIC strong has a positive significant coefficient). However, impatient investors are indifferent to the weak presence of strategic investors (the coefficient STRATEGIC few is not significant). The model also shows that being an impatient mutual fund 21 rather than a patient mutual fund increases the probability of preferring large stock markets (MARKETSIZE large has a positive significant coefficient), and being an impatient mutual fund rather than a patient mutual fund decreases the probability of preferring small and intermediary stock markets (MACA intermediate and MACA small have significant but negative coefficients). With the variable LEGAL ORIGIN we find that impatient funds prefer markets where they understand the legal system (LEGAL ORIGIN has a positive and significant coefficient). Last, with the variable SHAREHOLDER we highlight that being an impatient mutual fund rather a patient one decreases the probability of preferring a market with weak shareholder protection (the variable SHAREHOLDER has a significant but negative coefficient). We now turn to a ranking of mutual fund investment criteria (see Table 7).

Marginal effects (Table 7) indicate different sensibilities according to variables and enable the variables to be classified by order of importance for mutual funds. They indicate that the size of market capitalization of countries (an indicator of market liquidity) plays a central role for impatient mutual funds. Then come, in order of importance, 1) the level of shareholder protection (variable SHAREHOLDER), 2) the presence of strategic investors, and 3) the institutional distance.

The data of this paper cover the period before the subprime crisis (start 2005) and the year when the effects of the crisis start (beginning of the year 2009). Before the subprime crisis and in early 2009, mutual funds prefer to invest in large stock markets and markets with a high protection of shareholders. The collapse of international lending markets has shown the retraction of investors from international markets to the advantage of domestic markets and less risky markets ([49]). Because the degree of proximity to domestic market and the size of a market affect the perceived risk and expected

Table 7. Complete model Investors' location strategies-Dependent Variable "High"-marginal effects.

\begin{tabular}{|c|c|c|c|}
\hline Dependent Variables & $\begin{array}{l}\text { Marginal effects-dy/dx } \\
\qquad(2 a)\end{array}$ & $\begin{array}{l}\text { Marginal effects-dy/dx } \\
(2 \mathrm{~b})\end{array}$ & $\begin{array}{c}\text { Marginal effects-dy/dx } \\
(2 \mathrm{c})\end{array}$ \\
\hline Equity Asset & $0.0000156^{* * *}(7.07)$ & $0.0000155^{* * *}(7.07)$ & $0.00001^{\star * *}(6.87)$ \\
\hline Marketsize $_{\text {small }}$ & $-0.083^{\star * *}(-5.66)$ & $-0.080^{\star \star \star}(-5.47)$ & $-0.090^{\star \star \star}(-6.04)$ \\
\hline Marketsize $_{\text {intermediate }}$ & $-0.010^{* * *}(-4.46)$ & $-0.060^{* * *}(-4.46)$ & $-0.059^{* * *}(-4.36)$ \\
\hline Marketsize large & $0.0493^{* * *}(5.23)$ & $0.0491^{* * *}(5.21)$ & $0.045^{\star * *}(4.78)$ \\
\hline Strategic Investors strong & $0.027^{\star \star *}(2.77)$ & $0.031^{\star \star *}(3.17)$ & $0.030^{* * *}(3.05)$ \\
\hline Strategic Investors $\mathrm{few}_{\mathrm{ew}}$ & $0.0040(0.37)$ & $0.003(0.35)$ & $0.002(0.20)$ \\
\hline Shareholder protection & - & $-0.038^{\star * *}(-3.78)$ & $-0.038^{\star * \star}(-3.75)$ \\
\hline Institutional distance & - & - & $0.026^{\star * \star}(4.35)$ \\
\hline
\end{tabular}

$\mathrm{p}$-value: ${ }^{*} \mathrm{p}<0.10 ;{ }^{* *} \mathrm{p}<0.5 ;{ }^{* * *} \mathrm{p}<0.01$. Note: values in parentheses are $\mathrm{z}$-statistic. Note: $\mathrm{dy} / \mathrm{dx}$ is to discrete change of dummy variable from 0 to 1 . 
returns, investors have invested more on proximate markets, the most liquid markets (the largest ones) and markets with the highest protection for shareholders. Results obtained in this paper should therefore be robust and even stronger after the subprime crisis.

\section{Conclusion and Discussions}

Our findings contribute to a growing literature on the importance of geography to the study of global finance. We demonstrate that geography and the institutional frameworks of countries are two factors that help understand the way mutual funds, and in particular impatient mutual funds, select the countries in which to invest. More generally this study provides new insights into the mutual fund industry and offers evidence of mutual fund tendency (with a focus on impatient mutual funds) to select stocks in specific countries. First, despite financial globalization, the global mutual fund industry remains very focused on two geographical areas and five countries, all characterized by developed financial markets. Second, mutual funds prefer investing in nearby markets provided mutual funds come from countries where financial markets are developed. Third, some countries attract more impatient mutual funds than others: this is mostly the case in countries whose legal systems are based on the Anglo-Saxon model. Inversely, impatient mutual funds are under-represented in some countries (essentially countries following the European continental model). Finally, impatient mutual funds are comfortable with large stock markets, markets with a high level of protection for shareholders, and markets with an institutional proximity. More surprisingly, impatient mutual funds have a preference for companies with strategic investors (family owners, the state, etc.) as dominant shareholders of large listed companies. In markets with a strong presence of strategic investors, closed ownership structures promote higher volatility in market prices, which attract impatient mutual funds. Our study validates and completes the results of [48] according to which markets with strategic investors attract mutual funds: stock markets with strategic investors especially attract impatient mutual funds. This could be even more the case in the event of a reversal on financial markets in which the number of shares traded is considerably reduced, but there are no studies to date on this issue. These results open the way for new research in the field of the geography of finance that questions the relationship between location strategies of mutual funds and the liquidity of markets.

\section{References}

[1] Clark, G.L. (2002) London in the European Financial Services Industry: Locational Advantage and Product Complementarities. Journal of Economic Geography, 2, 433-453. http://dx.doi.org/10.1093/jeg/2.4.433

[2] Leyshon, A. (2008) Geographies of Money and Finance. Progress in Human Geography, 22, 443-446.

[3] Klagge, B. and Martin, R. (2005) Decentralized versus Centralized Financial Systems: Is There a Case for Local Capital Markets? Journal of Economic Geography, 5, 387-421. http://dx.doi.org/10.1093/jeg/lbh071 
[4] Pike, A. (2006) Shareholder Value versus the Regions: The Closure of the Vaux Brewery in Sunderland. Journal of Economic Geography, 6, 201-222. http://dx.doi.org/10.1093/jeg/lbi005

[5] Clark, G.L. and Wójcik, D. (2007) The Geography of Finance: Corporate Governance in the Global Marketplace. Oxford University Press, Oxford. http://dx.doi.org/10.1093/acprof:oso/9780199213368.001.0001

[6] Corpataux, J., Crevoisier, O. and Theurillat, T. (2009) The Expansion of the Finance Industry and Its Impact on the Economy: A Territorial Approach Based on Swiss Pension Funds. Economic Geography, 85, 313-334.

[7] French, S., Leyshon A. and Wainwright, T. (2011) Financializing Space, Spacing Financialization. Progress in Human Geography, 35, 789-819.

[8] Pike, A. and Pollard, J.S. (2010) Economic Geographies of Financialization. Economic Geography, 86, 29-51. http://dx.doi.org/10.1111/j.1944-8287.2009.01057.x

[9] Wójcik, D. (2011) Securitization and Its Footprint: The Rise of the US Securities Industry Centers 1998-2007. Journal of Economic Geography, 11, 925-947. http://dx.doi.org/10.1093/jeg/lbq045

[10] Markowitz, H.M. (1959) Portfolio Selection: Efficient Diversification of Investment. The Journal of Finance, 7, 77-91.

[11] Kahneman, D. and Tversky, A. (1979) Prospect Theory: An Analysis of Decision under Risk. Econometrica, 47, 263-292. http://dx.doi.org/10.2307/1914185

[12] Clark, G.L., Knox-Hayes, J. and Strauss, K. (2009) Financial Sophistication, Salience and the Scale of Deliberation in UK Retirement Planning. Environment and Planning A, 41, 24962515. http://dx.doi.org/10.1068/a41265

[13] French, K.R. and Poterba, J. (1991) Investor Diversification and International Equity Markets. American Economic Review, 81, 222-226. http://dx.doi.org/10.3386/w3609

[14] Tesar, L.L. (1995) Home Bias and High Turnover. Journal of International Money and Finance, 14, 467-492. http://dx.doi.org/10.1016/0261-5606(95)00023-8

[15] Falkenstein, E. (1996) Preferences for Stock Characteristics Are Revealed by Mutual Fund Portfolio Holdings. Journal of Finance, 51, 111-135. http://dx.doi.org/10.1111/j.1540-6261.1996.tb05204.x

[16] Kang, J.K. and Stulz, R. (1997) Why Is There a Home Bias? An Analysis of Foreign Portfolio Equity Ownership in Japan. Journal of Financial Economics, 46, 3-28. http://dx.doi.org/10.1016/S0304-405X(97)00023-8

[17] Coval, J.D. and Moscovitz, T.J. (1999) Home Bias at Home: Local Equity Preference in Domestic Portfolios. Journal of Finance, 54, 2045-2073. http://dx.doi.org/10.1111/0022-1082.00181

[18] Huberman, G. (2000) Home Bias in Equity Markets International and International Evidence. In: Hess, G.D. and Van Wincoop, E., Eds., International Macroeconomics, Chap. 4, Cambridge University Press, Cambridge.

[19] Glassman, D.A. and Riddick, L.A. (2001) What Causes Home Bias and How Should It Be Measured? Journal of Empirical Finance, 8, 35-54. http://dx.doi.org/10.1016/S0927-5398(00)00026-8

[20] Grinblatt, M. and Keloharju, M. (2001) How Distance, Language and Culture Influence Stockholdings and Trades. Journal of Finance, 56, 1053-1073. http://dx.doi.org/10.1111/0022-1082.00355

[21] Sarkissian, S. and Schill, M. (2004) The Overseas Listing Decision: New Evidence of Prox- 
imity Preference. The Review of Financial Studies, 17, 769-809.

http://dx.doi.org/10.1093/rfs/hhg048

[22] Chan, K., Covrig, V. and Ng, L. (2005) What Determines the Domestic Bias and Foreign Bias? Evidence from Mutual Funds Equity Allocation Worldwide. Journal of Finance, 60, 1495-1534. http://dx.doi.org/10.1111/j.1540-6261.2005.768 1.x

[23] Portes, R. and Rey, H. (2005) The Determinants of Cross-Border Equity Flows. Journal of International Economics, 65, 269-296. http://dx.doi.org/10.1016/j.jinteco.2004.05.002

[24] Clark, G.L. (1999) Pension Fund Capitalism. Oxford University Press, Oxford.

[25] Hawley, J.P. and Williams, A.T. (2000) The Rise of Fiduciary Capitalism: How Institutional Investors Can Make Corporate America More Democratic. University of Pennsylvania Press, Philadelphia.

[26] Hebb, T. (2006) The Economic Inefficiency of Secrecy: Pension Fund Investors' Corporate Transparency Concerns. Journal of Business Ethics, 63, 384-405. http://dx.doi.org/10.1007/s10551-005-3968-9

[27] Bauer, R., Braun, R. and Clark, G.L. (2008) The Emerging Market for European Corporate Governance: The Relationship between Governance and Capital Expenditures, 1997-2005. Journal of Economic Geography, 8, 441-469. http://dx.doi.org/10.1093/jeg/lbn018

[28] Martin, R. and Minns, R. (2005) Undermining the Financial Basis of Regions: The Spatial Structure and Implications of the UK Pension Fund System. Regional Studies, 29, 125-144. http://dx.doi.org/10.1080/00343409512331348853

[29] Froud, J., Haslam, C., Johal, S. and Williams, K. (2000) Shareholder Value and Financialization: Consultancy Promises, Management Moves. Economy and Society, 29, 80-110. http://dx.doi.org/10.1080/030851400360578

[30] Aglietta, M. and Rebérioux, A. (2004) Dérives du Capitalisme Financier. Albin Michel Economie, Paris.

[31] Goyer, M. (2006) Varieties of Institutional Investors and National Models of Capitalism: The Transformation of Corporate Governance in France and Germany. Politics and Society, 34, 399-430. http://dx.doi.org/10.1177/0032329206290427

[32] Dupuy, C., Lavigne, S. and Nicet-Chenaf, D. (2010) Geography Still Matter? Evidence on the Portfolio Turnover of Large Equity Investors and Varieties of Capitalism. Economic Geography, 86, 75-98. http://dx.doi.org/10.1111/j.1944-8287.2009.01055.x

[33] Clark, G.L. and Wójcik, D. (2003) An Economic Geography of Global Finance: Ownership Concentration and Stock Price Volatility in German Firms and Regions. Annals of the Association of American Geographers, 93, 909-924.

http://dx.doi.org/10.1111/j.1467-8306.2003.09304012.x

[34] Clark, G.L. (2006) Setting the Agenda: The Geography of Global Finance. In: Bagachi-Sen, S. and Lawton Smith, H., Eds., Past, Present and Future Economic Geography, Routledge, New York.

[35] Martin, R. (2011) The Local Geographies of the Financial Crisis: From the Housing Bubble to Economic Recession and Beyond. Journal of Economic Geography, 11, 587-618. http://dx.doi.org/10.1093/jeg/lbq024

[36] O’Sullivan, M. (2000) Contests for Corporate Control: Corporate Governance and Economic Performance in the United States and Germany. Oxford University Press, Oxford.

[37] Clark, G.L. and Hebb, T. (2004) Pension Fund Corporate Engagement: The Fifth Stage of Capitalism. Industrial Relations, 59, 142-171. http://dx.doi.org/10.7202/009130ar

[38] Coval, J.D. and Moskowitz, T. (2001) The Geography of Investment: Informed Trading and Asset Prices. Journal of Political Economy, 109, 811-841. http://dx.doi.org/10.1086/322088 
[39] Clark, G.L. and Wójcik, D. (2002) How and Where Should We Invest in Europe? An Economic Geography of Global Finance. http://ssrn.com/abstract=308539

[40] Clark, G.L., Wójcik, D. and Bauer, R. (2006) Geographically Dispersed Ownership and Inter-Market Stock Price Arbitrage-Ahold's Crisis of Corporate Governance and Its Implications for Global Standards. Journal of Economic Geography, 6, 303-322. http://dx.doi.org/10.1093/jeg/lbi018

[41] Warnock, F. (2002) Home Bias and High Turnover Reconsidered. Journal of International Money and Finance, 21, 795-805. http://dx.doi.org/10.1016/S0261-5606(02)00023-2

[42] Amable, B. (2003) The Diversity of Modern Capitalism. Oxford University Press, Oxford. http://dx.doi.org/10.1093/019926113X.001.0001

[43] Chan, K. and Covrig, V. (2012) What Determines Mutual Fund Trading in Foreign Stocks. Journal of International Money and Finance, 31, 793-817. http://dx.doi.org/10.1016/j.jimonfin.2012.01.003

[44] La Porta, R., Lopez-De-Silanes, F. and Shleifer, A. (1999) Corporate Ownership around the World. The Journal of Finance, 54, 471-517. http://dx.doi.org/10.1111/0022-1082.00115

[45] La Porta, R., Lopez-De-Silanes, F., Shleifer, A. and Vishny, R. (1998) Law and Finance. Journal of Political Economy, 106, 1113-1155. http://dx.doi.org/10.1086/250042

[46] La Porta, R., Lopez-De-Silanes, F., Shleifer, A. and Vishny, R. (2000) Investor Protection and Corporate Governance. Journal of Financial Economics, 58, 3-27. http://dx.doi.org/10.1016/S0304-405X(00)00065-9

[47] Shleifer, A. and Vishny, R.W. (1997) A Survey of Corporate Governance. Journal of Finance, 52, 737-783. http://dx.doi.org/10.1111/j.1540-6261.1997.tb04820.x

[48] Dahlquist, M., Pinkowitz, L., Stulz, R.M. and Williamson, R. (2003) Corporate Governance and the Home Bias. The Journal of Financial and Quantitative Analysis, 38, 87-110. http://dx.doi.org/10.2307/4126765

[49] Giannetti, M. and Laeven, L. (2012) The Flight Home Effect: Evidence from the Syndicate Loan Market during Financial Crisis. Journal of Financial Economics, 104, 23-43. http://dx.doi.org/10.1016/j.jfineco.2011.12.006 
Appendix 1: Market Capitalizations of Countries (2009, Million \$)

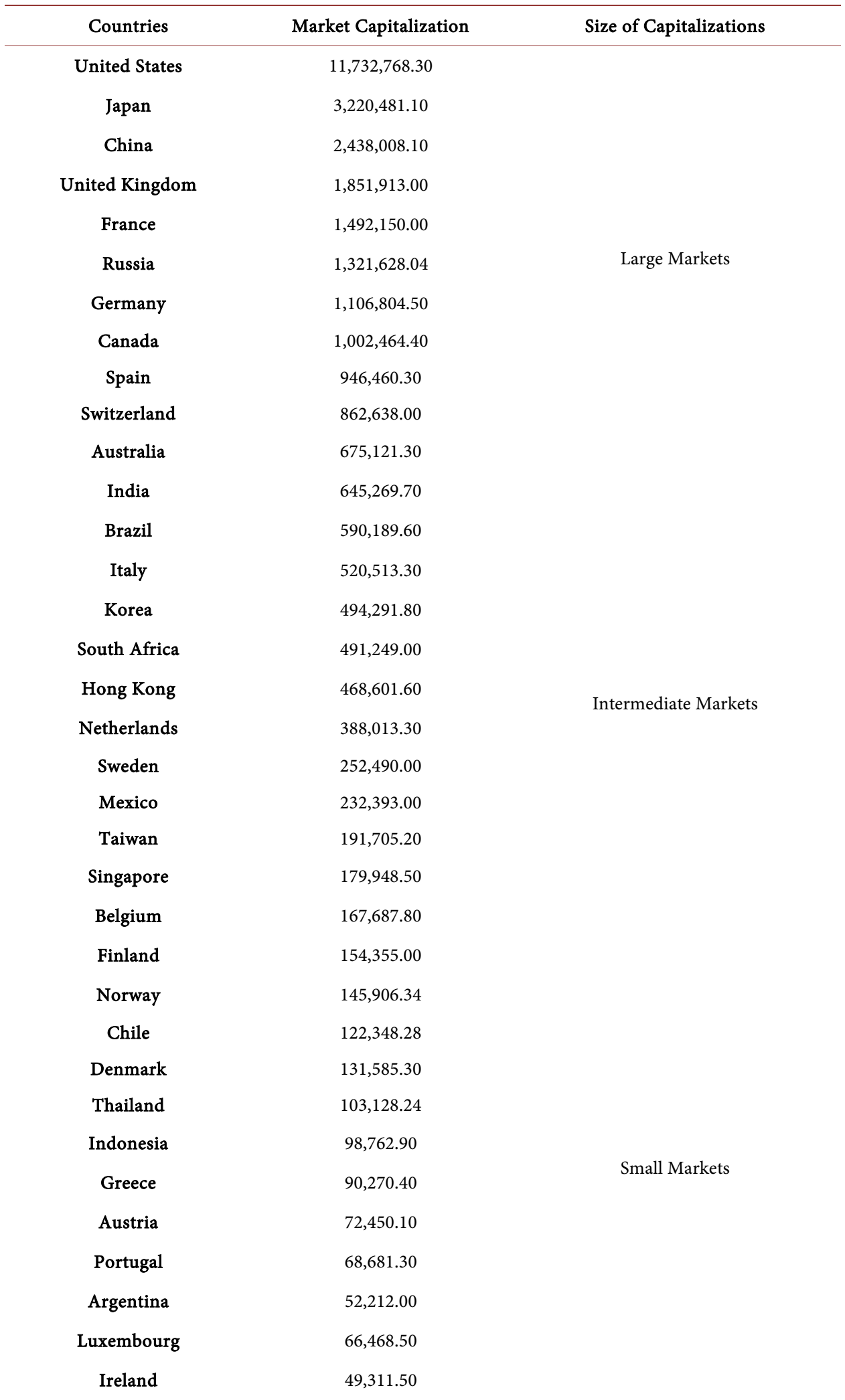

Source: International Monetary Fund, http://www.imf.org/external/index.htm. 
Appendix 2: Investors' Location Strategies (Verified by the Equity Asset, Variable "Low") (Probability of the Characteristic Y = 1, with the US as a Reference)

\begin{tabular}{|c|c|c|c|}
\hline Number of observations $=22,996$ & \multicolumn{3}{|c|}{ Iterations completed $=5$} \\
\hline Log likelihood function $=-8759.0379$ & \multicolumn{3}{|c|}{ Degrees of freedom $=35$} \\
\hline Chi squared $=349.40$ & \multicolumn{3}{|c|}{ Pseudo R-squared $=0.0196$} \\
\hline \multicolumn{4}{|l|}{$\operatorname{Prob}[$ ChiSqd $>$ value $]=0.000000$} \\
\hline Variables & Marginal Effects & z & $\mathrm{P}[\mathrm{Z} />\mathrm{z}]$ \\
\hline Equity Asset & -0.000003 & -4.01 & 0.000 \\
\hline India & -0.0586 & -7.98 & 0.0000 \\
\hline Russia & -0.0523 & -5.94 & 0.000 \\
\hline Brazil & -0.0329 & -5.62 & 0.000 \\
\hline Honk Kong & -0.272 & -3.50 & 0.000 \\
\hline Canada & -0.219 & -4.27 & 0.000 \\
\hline Netherlands & -0.0158 & -2.36 & 0.019 \\
\hline Australia & 0.0251 & 3.31 & 0.001 \\
\hline Portugal & 0.0239 & 2.35 & 0.019 \\
\hline China & 0.0142 & 1.66 & 0.097 \\
\hline Ireland & 0.0120 & 1.88 & 0.060 \\
\hline Argentina & 0.0478 & 1.59 & 0.113 \\
\hline Thailand & -0.0131 & -1.01 & 0.312 \\
\hline Italy & -0.0023 & -0.28 & 0.779 \\
\hline Austria & -0.0002 & -0.03 & 0.979 \\
\hline Finland & -0.0001 & -0.02 & 0.981 \\
\hline United Kingdom & 0.0012 & 0.22 & 0.0824 \\
\hline Sweden & -0.0053 & -0.68 & 0.495 \\
\hline Belgium & 0.0095 & 1.31 & 0.191 \\
\hline Japan & 0.0018 & 0.29 & 0.775 \\
\hline Taiwan & -0.0004 & -0.05 & 0.957 \\
\hline Greece & 0.0030 & 0.32 & 0.749 \\
\hline Norway & 0.0076 & 0.83 & 0.404 \\
\hline South Africa & 0.0151 & 1.53 & 0.126 \\
\hline Korea & 0.00002 & 0.00 & 0.998 \\
\hline Denmark & 0.0074 & 0.82 & 0.410 \\
\hline Mexico & -0.0017 & -0.17 & 0.868 \\
\hline Spain & 0.0043 & 0.60 & 0.551 \\
\hline Indonesia & -0.0029 & -0.21 & 0.833 \\
\hline France & -0.0126 & -1.62 & 0.105 \\
\hline Luxembourg & 0.0041 & 0.71 & 0.477 \\
\hline Chile & -0.0240 & -1.62 & 0.106 \\
\hline Germany & -0.0108 & -1.38 & 0168 \\
\hline Singapore & -0.0005 & -0.08 & 0.940 \\
\hline Switzerland & 0.0076 & 1.25 & 0.212 \\
\hline
\end{tabular}

In the grayed parts the variables are not significant. In this estimation the $\mathrm{z}$ statistic indicates that few coefficients are significant at the risk level of $1 \%(\mathrm{P}[\mathrm{Z} />\mathrm{z}]<0.000)$. The explanatory capacity of the model is weaker for patient investors. However the model shows once again that there are two types of investor strategies in relation to the U.S. market: being a "patient" investor rather than an "impatient" investor decreases the probability of preferring the following countries for investments: India, Russia, Brazil, Honk Kong, Canada and the Netherlands. Being a "patient" investor rather an "impatient" investor increases the probability of preferring the following countries for investments: Australia, Portugal, China and Ireland. These investors are less inclined to choose Indian or Russian markets than Canadian markets. In the same way, investments in Australia are characterized by high positive elasticities compared with low positive elasticities for China. Investors are more inclined to choose Australia than China. 
Submit or recommend next manuscript to SCIRP and we will provide best service for you:

Accepting pre-submission inquiries through Email, Facebook, LinkedIn, Twitter, etc. A wide selection of journals (inclusive of 9 subjects, more than 200 journals)

Providing 24-hour high-quality service

User-friendly online submission system

Fair and swift peer-review system

Efficient typesetting and proofreading procedure

Display of the result of downloads and visits, as well as the number of cited articles

Maximum dissemination of your research work

Submit your manuscript at: http://papersubmission.scirp.org/

Or contact jmf@scirp.org 